\title{
An Integrated Information System for Selection of Areas Tourist Sites Using Clustering and Electre Methods
}

\author{
Arlieza Anindyaputri \\ Information Systems Program \\ Diponegoro University \\ Semarang, Indonesia \\ ichaputri9999@gmail.com
}

\author{
Jatmiko Endro Suseno \\ Department of Physics \\ Faculty of Science and Mathematics \\ Diponegoro University \\ Semarang, Indonesia \\ jatmikoendro@gmail.com
}

\author{
Catur Edi Widodo \\ Department of Physics \\ Faculty of Science and Mathematics \\ Diponegoro University \\ Semarang, Indonesia \\ catur.ediwidodo@gmail.com
}

\begin{abstract}
Tourism is currently being vigorous in various circles. The community really this idea of sharing info through social media with upload tourism objects of photos which are the creations. As for the constraints of society in search of tourism objects in a town in visit in terms of the distance, the existing facilities at tourism place and the price of admission which has not known the information in social media. In Decision support system, there are several methods in solving this problem is one of clustering method and Electre method. Clustering method is needed in the mining of data a multicenter problem. Combining data in a group is an important problem in interpreting the data and efficient data algorithm is needed, while the electre method in the system can help analyze data and make decisions to travel in accordance with the estimation of types of attractions, tourist facilities, distance from the city center, tickets enter the tourist sites and produce tourist recommendations.
\end{abstract}

Keywords_Decision Support System; Clustering; Electre

\section{INTRODUCTION}

A technology system that can know everything about tourist attraction quickly. Aimed at applying information system to introduce tourism and assist in searching the destination so as to generate recommendation of tourism according to criterion of tourist object like Tour Type, Distance, Facilities and Admission Price [1]. Ranking the recommendations using the Electre method.

Clustering method was used in the study are useful to category grouping an array of tourism consisting of the natural attraction, water tourism, tour of , education tourism , cultural heritage tourism, religious tourist destination, village tourism.

\section{MethodOlOGY}

\section{A. Clustering K-means}

K-Means is a clustering in data mining and which is widely used for clustering large data sets. This k-means algorithm is one of the simplest Algorithms of learning. This method is useful for classifying objects [3]. The calculation step or grouping using K-Means Clustering method such as: Step 1: Determine the many K-clusters to be formed, Step 2: Generating a random value for the center cluster (Centroid) as much as k. [4], and Step 3: Calculates the distance of each input data to each centroid using the Eucledian Distance formula until it finds the closest distance of each data with the centroid.

Here is the Eucledian Distance equation:

$$
d\left(x_{i}, \mu_{j}\right)=\sqrt{\left(x_{i}-\mu_{j}\right)^{2}}
$$

Step 4 : Classify each data verdasarkan its proximity to the centroid (smallest distance).

Step 5 : Updating the centroid value. The new centroid value is obtained from the average cluster in question by using the formula:

$$
\mu_{j}(t+1)=\frac{1}{N_{S j}} \sum_{j \in S j} x_{j}
$$

Step 6 : Repeat from step 2 to 5 until the members of each cluster nothing changes.

Step 7 : If step 6 has been fulfilled, then the average value of the cluster center $(\mu \mathrm{j})$ in the last iteration will be used as a parameter for Radial Basis Function in the hidden layer. 


\section{B. Electre (Elimination Et Choix Traduisant la Realite)}

Electre is a multicriteria decision-making method based on the concept of outranking by using pairwise comparisons of alternatives based on each appropriate criterion [2]. The steps taken to solve the problem with the Electre method are as follows:

Step 1: Normalization of decision matrix. Establish a pairwise comparison on each alternative in each criterion (xij).

Values should be normalized to a comparable scale (rij) can be done by formula (3) :

$r_{i j}=\frac{x_{i j}}{\sqrt{\sum_{i=1}^{m} x^{2_{i j}}}}$, untuk $i=1,2,3, \ldots, m$ dan $j=1,2,3, \ldots, n$.

So that obtained matrix $\mathrm{R}$ result of normalization,

$$
R=\left|\begin{array}{llll}
11 & r_{12} & \cdots & r^{1 n} \\
r_{21} & r_{22} & \cdots & r_{2 \mathrm{n}} \\
\cdots & & & \\
r_{m 1} & r_{m 2} & \cdots & r_{m n}
\end{array}\right|
$$

Step 2: Weighted in a normalized matrix.

After normalization, each column of the matrix $\mathrm{R}$ is multiplied by the weight (wj) determined by the decision maker. Thus, the weighted normalized matrix is $\mathrm{V}=\mathrm{RW}$ written in this (4) formula:

$V=\left[\begin{array}{llll}v_{11} & v_{12} & \ldots & v_{1 \mathrm{n}} \\ v_{21} & v_{22} & \ldots & v_{2 \mathrm{n}} \\ \ldots & & & \\ v_{m 1} & v_{m 2} & \ldots & v_{m n}\end{array}\right]=R W=\left[\begin{array}{llll}w_{1} r_{11} & w_{2} r_{12} & \ldots & w_{n} r_{1 \mathrm{n}} \\ w_{1} r_{21} & w_{2} r_{22} & \ldots & w_{n} r_{2 \mathrm{n}} \\ \ldots & & & \\ w_{1} r_{m 1} & w_{2} r_{m 2} & \ldots & w_{n} r_{m n}\end{array}\right]$

where $\mathrm{W}$ is

$$
W=\left[\begin{array}{ccccc}
w_{1} & 0 & 0 & \ldots & 0 \\
0 & w_{2} & 0 & \ldots & \\
\ldots & & & & \\
0 & 0 & 0 & \ldots & w_{n}
\end{array}\right] \text {, dan } \sum_{i=1}^{n} w=1
$$

Step 3: Determine concordance and discordance set.

For each pair of alternatives $\mathrm{k}$ and $\mathrm{l}(\mathrm{k}, \mathrm{l}=1,2,3, \ldots, \mathrm{m}$ and $\mathrm{k} \neq$ l) the set of criteria $j$ is divided into two subsets, namely concordance and discordance. When a criterion in an alternative including concordance is:

$\mathrm{C}_{\mathrm{kl}}=\{\mathrm{j}, \mathrm{ykj} \geq \mathrm{ylj}\}$, untuk $\mathrm{j}=1,2,3, \ldots, \mathrm{n}$
In contrast, the complementary of this subset is discordance, ie when:

$\mathrm{D}_{\mathrm{kl}}=\{\mathrm{j}, \quad \mathrm{ykj}<\mathrm{ylj}\}, \quad$ untuk $\mathrm{j}=1,2,3, \ldots, \quad \mathrm{n}$ (7)

Step 4: Calculate concordance and discordance matrices.

- Concordance

To determine the value of the elements in the concordance matrix is to add the weights included in the concordance subset, mathematically in Formula (8):

$$
c_{k l}=\sum_{j C_{w}} w_{j}
$$

So the resulting concordance matrix is:

$$
C=\left[\begin{array}{lllll}
- & c_{12} & c_{13} & \ldots & c_{1 \mathrm{n}} \\
c_{21} & - & c_{23} & \ldots & c_{2 \mathrm{n}} \\
\ldots & & & & \\
c_{m 1} & c_{m 2} & c_{m 3} & \ldots & -
\end{array}\right]
$$

\section{- Discordance}

To determine the value of the elements in the discordance matrix is to divide the maximum of the difference of the criterion value included in the discordance subset with the maximum difference in the value of all the existing criteria, mathematically as follows:

$$
d_{k l}=\frac{\left\{\max \left(v_{m n}-v_{m n-\ln }\right)\right\} ; m, n \& D_{k l}}{\left\{\max \left(v_{m n}-v_{m n-\ln }\right)\right\} ; m, n=1,2,3, \ldots}
$$

So the discordance matrix is obtained:

$$
D=\left[\begin{array}{lllll}
- & d_{12} & d_{13} & \ldots & d_{1 \mathrm{~m}} \\
d_{21} & - & d_{23} & \ldots & c_{2 \mathrm{~m}} \\
\ldots & & & & \\
d_{m 1} & d_{m 2} & d_{m 3} & \ldots & -
\end{array}\right]
$$

Step 5: Determines the dominant matrix of concordance and discordance.

\section{a. Concordance}

The dominant concordance matrix can be constructed with the help of the threshold value, by comparing each value of the concordance matrix element with the threshold value

$$
\mathrm{Ckl} \geq \mathrm{c}
$$

with the threshold value (c), are:

$$
\underline{c}=\frac{\sum_{k=1}^{n} \sum_{l=1}^{n} c_{k l}}{m *(m-1)}
$$


and the value of each element of the matrix $\mathrm{F}$ as the dominant concordance matrix is determined as follows:

$$
\mathrm{fkl}=1 \text {, if } \mathrm{ckl} \geq \mathrm{c} \text { and } \mathrm{fkl}=0 \text {, if } \mathrm{ckl}<\mathrm{c}
$$

- Discordance

To construct the dominant matrix of discordance also use the help of threshold value, that is:

$$
\underline{d}=\frac{\sum_{k=1}^{n} \sum_{l=1}^{n} d_{k l}}{m *(m-1)}
$$

and the value of each element for the matrix $G$ as the dominant matrix of discordance is determined as follows:

$$
\begin{gathered}
\mathrm{gkl}=1, \text { if } \mathrm{ckl} \geq \mathrm{d} \\
\text { dan } \\
\mathrm{gkl}=0 \text {, if } \mathrm{ckl}<\mathrm{d}
\end{gathered}
$$

Step 6: Specifies aggregate dominance matrix.

The next step is to determine the aggregate dominance matrix as the matrix E, which each element is a multiplication of the matrix element $\mathrm{F}$ with the matrix element $\mathrm{G}$, as follows:

$$
\mathrm{ekl}=\mathrm{fkl} \mathrm{xgkl}
$$

Step 7: Alternative elimination.

Matrix E gives a sequence of options from each alternative, ie when ekl $=1$ then alternative $\mathrm{Ak}$ is a better choice than $\mathrm{Al}$. Thus the row in the matrix $\mathrm{E}$ which has the least amount of ecl $=1$ can be eliminated. Thus the best alternative is that which dominates other alternatives.
TABLE I. INFORMATION SYSTEM FRAMEWORK

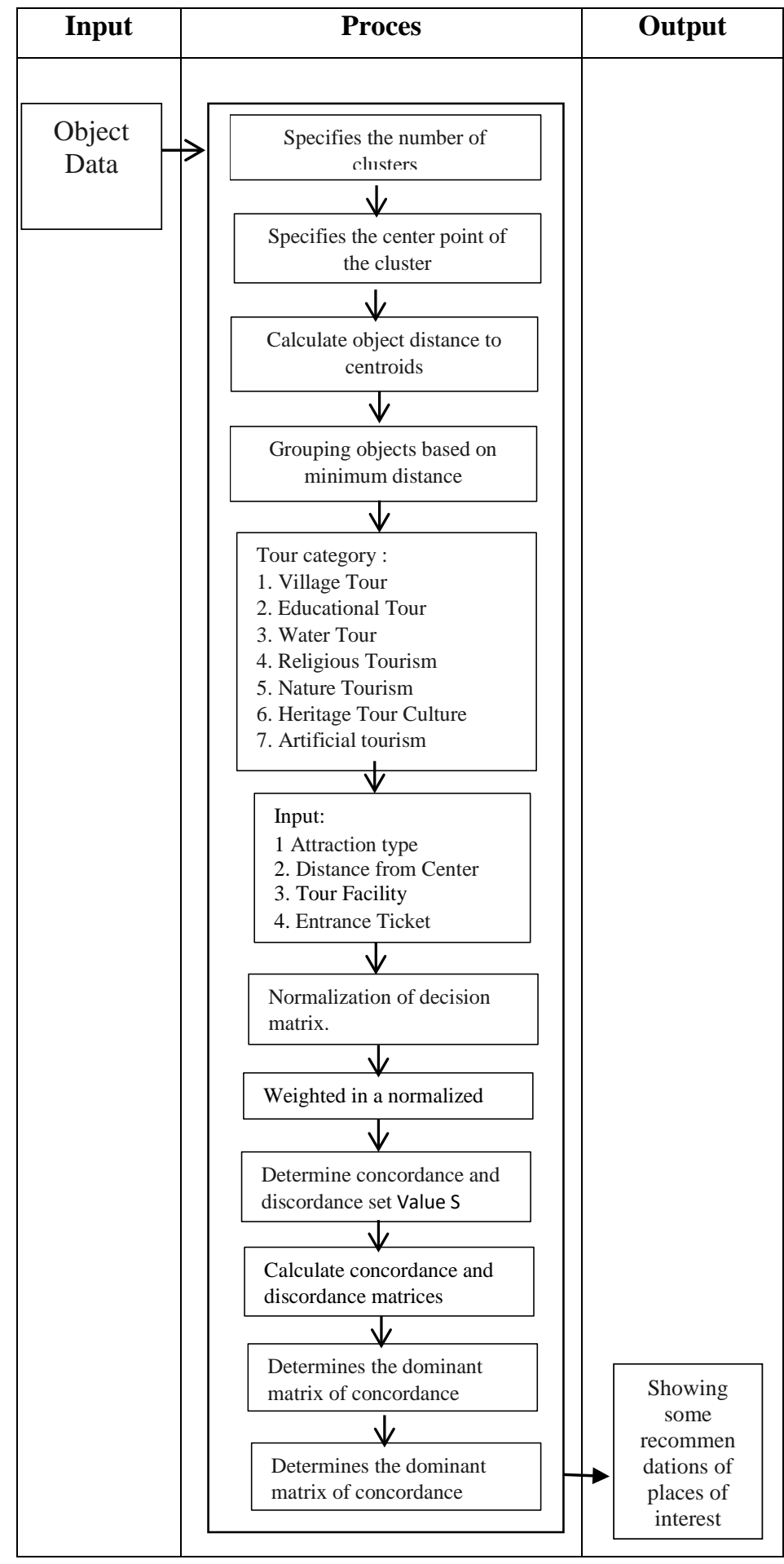

\section{RESULTS}

The first step is done by grouping the data based on the types of tours, Distance from Center, that use the method of kmeans clustering. In this study, using case study data in the 
city of Semarang. The city of Semarang has 45 locations of tourist attractions.

TABLE II. SAMPLE DATA

\begin{tabular}{|l|l|c|l|l|c|}
\hline No & Restaurant & C1 & C2 & C3 & C4 \\
\hline 1 & Gereja Blenduk & 4 & 3 & & 4 \\
\hline 2 & Goa Kreo & 5 & 2 & & 3 \\
\hline 3 & Kampung Pelangi & 7 & 3 & & 3 \\
\hline 4 & Water Blaster & 3 & 3 & & 1 \\
\hline 5 & Desa Kandri & 1 & 2 & & 2 \\
\hline 6 & Musium & 2 & 3 & & 2 \\
\hline 7 & Konggowarsito & 6 & 3 & & 4 \\
\hline 8 & Citra Grand Semarang & 7 & 3 & & 4 \\
\hline 9 & Waduk Jatibarang & 3 & 2 & & 3 \\
\hline 10 & Desa Nongkosawit & 1 & 1 & & 3 \\
\hline 11 & Taman Tinjo Moyo & 5 & 3 & & 2 \\
\hline 12 & Gereja Gedangan & 4 & 3 & & 4 \\
\hline 13 & Taman Budaya Raden & 2 & 3 & & 3 \\
\hline 14 & Paleh & 6 & 3 & & 4 \\
\hline 15 & Pantai Maron & 3 & 3 & & 3 \\
\hline 16 & Grand Maerakaca & 7 & 3 & & 3 \\
\hline 17 & vihara mahavira graha & 4 & 3 & & 2 \\
\hline 18 & Musium Jamu Jago & 2 & 3 & & 3 \\
\hline 19 & Desa Wonolopo & 1 & 1 & & 2 \\
\hline 20 & Taman Margasatwa & 5 & 3 & & 3 \\
\hline
\end{tabular}

Information C1 (type of tours) :

$1=$ Village Tour

2 = Educational Tour

3 = Water Tour

$=$ Religious Tourism

$=$ Nature Tourism

$=$ Heritage Tour Culture

$=$ Artificial tourism

Information C2 (Distance from Center) :

3 = Close (Range 0-6.9)

2 = Medium Distance (Range 7-14)

1 = Far (Range 14-20)

Information C4 (Entrance Ticket):

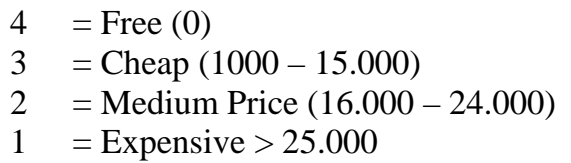

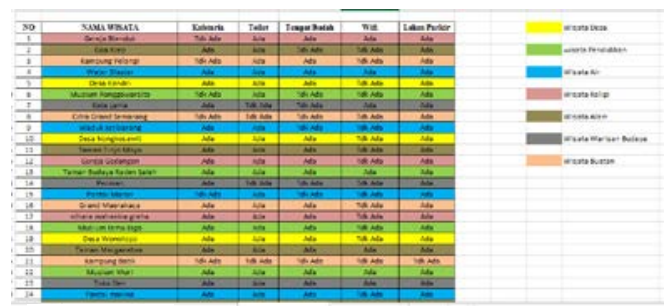

Fig. 1. Tour Facility

The tourist facilities contained none or none of the following: (1) Cafeteria, (2) Toilet, (3) Worship Place, (4) Wifi, (5), and Parking lot.

Tour Program Interface:

- $\quad$ Main Menu

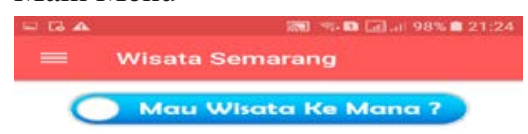

Fig. 2. Main Menu

This menu contains the main view

- $\quad$ Search Menu

To Enter in this menu can press button "Mau Wisata Kemana ?”

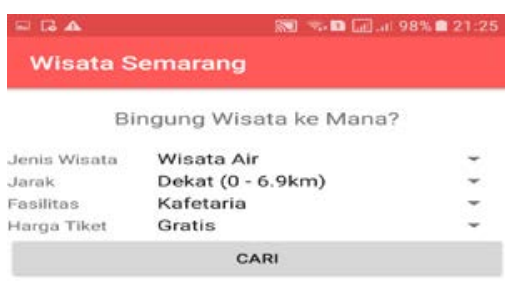

Fig. 3. Search Menu

This menu is used for quick search tours that we want according to the criteria that have been provided and provide tourist recommendation information. Result Tour Recommendation:

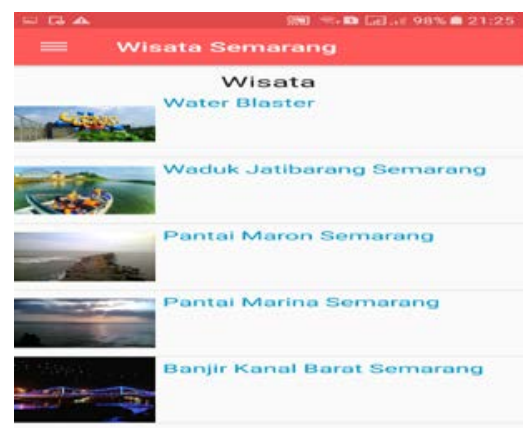

Fig. 4. Tour Recommendation 
- $\quad$ Cluster Type of Tours

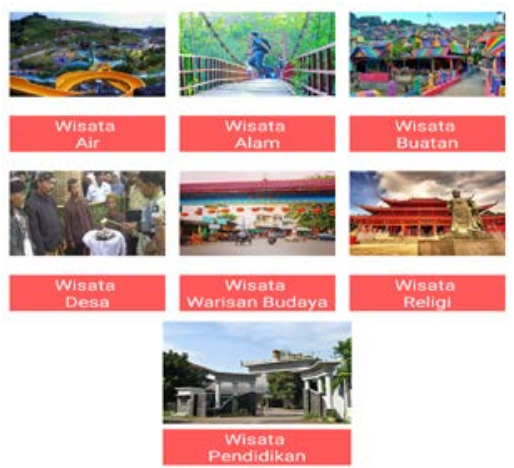

Fig. 5. Cluster Type of Tours

The classification of Semarang City tourism data by Category of tourist type.

\section{CONCLUSIONS}

Information systems to determine places that can be used to determine the categories of tourism products and assessed as desired. Tourist type consists of Village Tour, Educational Tour, Water Tour, Religious Tour, Nature Tour, Cultural Heritage Tour and Artificial Tour. Methods that allow users to search for places desired by users, distance, facilities and Ticket prices. With this system, users can no longer access it, users can also search for places to be cultivated.

\section{REFERENCES}

[1] A. Y. Wicaksono, R. Rismanto, and A. Prasetyo, "Pengembangan Aplikasi Sistem Informasi Rekomendasi Tempat Wisata di Kota Batu Menggunakan Metode Electre [Development of the Information System Application of Tourist Sites Recommendation in Batu City using Electre Method]," vol. 3, pp. 32-38, 2017.

[2] O. Pareira, A. J. Santoso, and P. Ardanari, "Sistem pendukung keputusan pemilihan tempat wisata di timor leste dengan metode electre [Supporting system of tourist sites choice decision in Timor Leste using Electre method],” J. Dili Inst. of Technol., Atma Jaya Univ., Yogyakarta, pp. 10-15, 2014.

[3] S. Na, G. Yong, and L. Xumin, "An Improved k-means Clustering Algorithm,” J. Int. of Prod. Res., IEEE, no. 10, pp. 978-981, 2010.

[4] A. Masruro, Kusrini, and E. T. Luthfi, "Sistem Penunjang Keputusan Penentuan Lokasi Wisata Menggunakan K-Means Clustering Dan Topsis (Supporting System of Tourism Sites Determination Decision using K-Means Clustering and Topsis,” Thesis, Jurnal Ilmiah DASI, vol. 15 , pp. $1-5,2014$.

[5] K. Cao, and Z. Yang, "A study of e-commerce adoption by tourism websites in China,” J. Int. of Destin. Mark. \& Manage., vol. 5, pp. 283289, 2016.

[6] J. Thor, S. Ding, and S. Kamaruddin, "Comparison of Multi Criteria Decision Making Methods From The Maintenance Alternative Selection Perspective,” Int. J. of Eng. Sci., vol. 2, pp. 27-34, 2013.

[7] M. Kenteris, D. Gavalas, and A. Mpitziopoulos, "A Mobile Tourism Recommender System,” J. Int. of Cult. Technol. and Commun., IEEE, pp. 4244-7755, 2010.

[8] Amir, Ahmad, Lipika, and Dey, "Ak-mean clustering algorithm for mixed numeric and categorical data,” J. Int. of Data \& Knowl. Eng., no. 63, pp. 503-527, 2007.

[9] J.P. Bousset, "A decision support system for integrated tourism development: Rethinking tourism policies and management strategies," Tour. Geogr., vol. 9, no. 4, pp. 387-404, 2007. 